\title{
PREDICTION OF THE COMPOSITION OF FRESH PASTURES BY NEAR INFRARED REFLECTANCE OR INTERACTANCE-REFLECTANCE SPECTROSCOPY
}

\author{
Daniel Alomar1*, Rita Fuchslocher, José Cuevas, Rodrigo Mardones, and Emilio Cuevas
}

\begin{abstract}
Fast and precise analytical tools can contribute to optimize pasture management decisions. This work was carried out to evaluate the potential of one such technique, near infrared spectroscopy (NIRS), to predict the nutritional value of pastures without previous drying of the samples, comparing two forms of collecting the spectra: reflectance, or interactance-reflectance (fiber optic probe). Samples $(n=107)$ from different swards were taken across the humid and temperate regions (Los Ríos and Los Lagos) of southern Chile. Once their spectra were collected, dry matter (DM) and several chemical constituents, such as crude protein (CP), metabolizable energy (ME), neutral (NDF) and acid detergent fiber (ADF), soluble carbohydrates (SC), soluble crude protein (SCP) and neutral detergent insoluble N (NDFIN), were determined as reference data. Calibrations were developed and the best ranked were selected (by cross-validation) according to a lower standard error of cross validation ( $\left.\mathrm{SE}_{\mathrm{CV}}\right)$ and a higher determination coefficient of cross validation $\left(\mathrm{R}^{2}{ }_{\mathrm{CV}}\right)$. Calibrations in the reflectance mode, for $\mathrm{DM}$ and $\mathrm{CP}$, reached a high $\mathrm{R}^{2}{ }_{\mathrm{CV}}$ (0.99 and 0.91, respectively) and a $\mathrm{SE}_{\mathrm{CV}}$ (6.5 and $18.4 \mathrm{~g} \mathrm{~kg}^{-1}$ ). Equations for ADF, SCP and ME were ranked next, with $\mathrm{R}^{2} \mathrm{CV}$ of $0.87,0.84$ and 0.82 , respectively, and $\mathrm{SE}_{\mathrm{CV}}$ of $15.88 \mathrm{~g} \mathrm{~kg}^{-1}, 15.45 \mathrm{~g} \mathrm{~kg}^{-1}$ and $0.34 \mathrm{Mj} \mathrm{kg}^{-1}$. Equations for NDF, SC and NDFIN, with $\mathrm{R}^{2}{ }_{\mathrm{CV}}$ of $0.78,0.77$ and 0.61 , respectively, and $\mathrm{SE}_{\mathrm{CV}}$ of $35.57,94.54$ and $1.89 \mathrm{~g} \mathrm{~kg}^{-1}$, respectively, are considered unreliable for prediction purposes. Interactance-reflectance, on the other hand, resulted in poorer equations for all fractions.
\end{abstract}

Key words: pasture composition; NIR prediction; near infrared reflectance spectroscopy, fresh pastures, fiber optics.

\section{INTRODUCTION}

Near infrared reflectance spectroscopy (NIRS) has been widely used as a fast, reliable and multiple method for evaluating the quality of forages, as well as other agricultural products. This technique is based on the absorption properties of the sample in the near infrared (NIR) electromagnetic region, explained by the chemical bonds present in the specimen being scanned, particularly those bonds involving hydrogen (Deaville and Flinn, 2000). The spectrum resulting from the molecular vibration mechanisms can be complicated by a multitude of factors, but with current capabilities, even when the entire spectrum is not understood, it is still possible to extract useful information by employing multivariate calibration methods to construct empirical models that relate relevant spectral variability of a population of samples to its chemical nature (Miller, 2001).

${ }^{1}$ Universidad Austral de Chile, Facultad de Ciencias Agrarias, P.O. Box 567, Valdivia, Chile.

"Corresponding author (dalomar@uach.cl).

Received: 10 January 2008.

Accepted: 12 May 2008.
In the case of forages and other materials of agricultural origin, most of the NIRS work has been performed with dry samples, as the high water content in the typical "natural" condition of fresh pasture samples presents some difficulties. Water, quantitatively the most important constituent in fresh forages and other agricultural materials, can be a challenge in the laboratory processing of fresh samples, imposing difficulties in grinding and affecting particle size and shape. Water can also affect the reliability of the detectors in the upper NIR range (Williams, 2001), as it provokes strong absorption signals that overlap and obscure other spectral features and can cause non-linear responses (Reeves, 2000). On the other hand, if samples could be scanned in their fresh, undried state, and their composition or nutritional value predicted within acceptable limits, an approach for fast and reliable predictions in the field could develop, as the industry devises more portable NIR equipment and computers, without sacrificing accuracy. Alternatively, samples arriving at the laboratory could be instantly predicted without the delay of the drying process, which can also alter chemical bonds, affecting the spectrum and, as a result, the perception of some compositional fractions 
(Alomar et al., 1999); Alomar et al., 2003; Deinum and Maassen, 1994. Natural samples, as fresh forage, can be scanned in special rectangular cells, which present a large sample area exposed to NIR radiation in comparison to traditional circular cells. The forage couvette can be inserted in a transport module that allows the sample to be scanned and its NIR reflectance spectrum collected across the long axis of its surface, as the cell is displaced by the mechanism. An alternative to the above is to apply fiber optics technology, which could be interesting when operating under environmental conditions not suitable for sensitive equipment (Osborne et al., 1993). Fiber optics could be attractive for work under field conditions, but the performance of technology on fibrous materials needs to be evaluated. One problem is that optic probes normally have a small scanning area, especially if compared with a large forage cell. Although a higher sampling error could be produced, this could be partially overcome by taking several readings for each sample, assuming that errors occur at random.

The objective of the present study was to assess the potential of predicting the nutritional value of different types of pastures in a fresh, undried condition by near infrared technology, developing calibrations with the spectra taken by reflectance on a large forage cell and by interactance reflectance, by means of a fiber optics probe.

\section{MATERIALS AND METHODS}

\section{Pasture sampling}

One hundred and seven samples of different types of swards were collected from different paddocks in 13 farms at different locations ( 39 and $42^{\circ} \mathrm{S}, 72^{\circ} \mathrm{W}$ ) in the temperate, humid Los Ríos and Los Lagos Regions, Southern Chile. Samples were hand clipped at $5 \mathrm{~cm}$ from soil, from March 2001 to May 2002, approximately at 1 to 2 wk intervals, covering different seasons, growth stages, predominant species, geographical positions, soil types and other factors that could account for sources of variation in nutritional value and spectral features. The forage obtained represented mixed permanent swards (comprising different proportions of grasses of the genera Lolium, Agrostis, Holcus, Bromus and Dactylis), but also legumes such as alfalfa (Medicago sativa L.) and clovers (mostly Trifolium pratense L. and T. repens L.) and annual lawn of oats (Avena sativa L.) or barley (Hordeum vulgare L.). Several broad-leaved species were also present in different proportions.

\section{Spectra collection}

Fresh samples, 1 to $2 \mathrm{~kg}$, were taken to the laboratory, cut to 2 to $3 \mathrm{~cm}$ with hand shears, thoroughly homogenised by hand and scanned in a Foss-NIRSystems 6500 scanning monochromator (Silver Springs, Maryland, USA) with accessories (as below) from the same manufacturers, all controlled by a personal computer and software NIRS 3 from Infrasoft International (ISI, Port Matilda, Pennsylvania, USA). Optical data, transformed to microabsorbance units $(\log 1 / \mathrm{R})$, were stored in suitable files. Spectra were collected either in reflectance, with a large rectangular cell with a quartz window providing $60 \mathrm{~cm}^{2}$ of sampling area (Part Number NR-7080, and inserted in a transport module (Part Number NR-6511), or in interactance reflectance with an optic fiber-optic probe (Part Number NR-6775), comprising a double bundle of concentric silica fibers (210 inner illuminators/210 external collectors of diffuse reflected radiation). The probe containing the fiber bundle is protected by an external steel jacket. In the case of the reflectance readings, three scans were taken by rearranging the sample in the cell, averaged and stored. In the case of the interactance reflectance option, samples were packed in opaque polyvinyl chloride (PVC) tubes $(25 \times 11 \mathrm{~cm})$ with same material caps at both ends and three perforations along main axis, enabling the fiber probe to be tightly introduced to irradiate the sample and collect the readings. In this way, three readings were collected for each sample and stored as described above. As the probe used has the option to adjust the distance between the end of the fiber bundle and the end of the external jacket (path length to the sample), spectra were taken at distances of $0,0.5,1,3$ and $5 \mathrm{~mm}$. Accessories for two modes of scanning samples were attached consecutively to the same monochromator as each new batch of new collected samples were scanned. Two events that took place along the experimental period are worth mentioning, as they affected spectral data and eventually the calibrations obtained: the first was a change of the light source (lamp) in November 2001, and the second a routine adjustment in the monochromator in January 2002.

\section{Chemical analysis}

After spectra were collected, samples were dried in a forced-air oven at $60{ }^{\circ} \mathrm{C}$ for $48 \mathrm{~h}$, ground in a laboratory mill (Thomas Wiley model 4, Arthur Thomas \& Co. Philadelphia, Pennsylvania, USA) with a $1 \mathrm{~mm}$ screen, and analysed for residual dry matter (DM) using oven at $105^{\circ} \mathrm{C}$ for $12 \mathrm{~h}$, crude protein (CP) by Kjeldahl and crude fiber (CF), following AOAC (1996) procedures (method 978.10); soluble crude protein (SCP) after Licitra et al. (1996), neutral detergent (with sodium sulfite and alpha amylase) fiber (NDF) after Van Soest et al. (1991), acid detergent fiber (ADF) after AOAC (1996) method 973-18, neutral detergent insoluble nitrogen (NDFIN), combining methods for NDF with Kjeldahl, as above; and digestible 
organic matter in dry matter (DOMD) by the two-stages in vitro digestibility method of Tilley and Terry (1963), modified by incubating (both stages) in an oven at 39 ${ }^{\circ} \mathrm{C}$ in closed flasks. DOMD was in turn used to estimate metabolizable energy (ME) according to a regression on in vivo values developed previously in our laboratory (Garrido and Mann, 1981).

\section{Calibrations}

Regression equations were adjusted relating spectral data to fractions determined by the reference methods. Calibration models were developed with the software WinISI II from Foss, NIRSystems (Silver Spring, MD), testing different mathematical treatments of the spectra (differentiation order, subtraction gap, smoothing interval), with or without applying Standard Normal Variance (SNV) and Detrend for scatter correction of the spectra. SNV scales each spectrum to have a standard deviation of 1.0 to help reduce particle size effects, and Detrend removes the linear and quadratic curvature of each spectrum (ISI, 1999). The regression method chosen was modified partial least squares.

The same calibration approach was used for spectra collected in reflectance (transport module) and interactance reflectance (fiber optics). However, while in the first group the full spectra were used $(400-2500 \mathrm{~nm})$, in the second the spectra were trimmed, excluding the range of $400-1100 \mathrm{~nm}$, since the detectors of the interactance reflectance probe are not suitable for that segment.

Cross validation was performed by dividing the set of samples in groups, to adjust the maximum number of terms (to avoid overfitting) and to select the best equations, i.e. those having a lower standard error of cross validation (SECV) and a higher determination coefficient of the cross validation $\left(\mathrm{R}^{2} \mathrm{CV}\right)$. Four cross validation groups and two passes of elimination of outliers were defined. A critical $\mathrm{T}$ value of 2.5 was set for "T outliers", i.e., samples with abnormally high residuals of predicted versus reference values.

\section{RESULTS AND DISCUSSION}

\section{Chemical composition}

The compositional data for the samples (Table 1) showed a wide variability in composition of analytical data, which confirms the important differences among sampled pastures.

Values for DM in the range of $100 \mathrm{~g} \mathrm{~kg}^{-1}$ reflect full vegetative growth, typical of mid to late winter. This is also confirmed by unusually high contents of CP, above $330 \mathrm{~g}$ $\mathrm{kg}^{-1} \mathrm{DM}$, for this type of plant material. On the other hand, samples from mature swards are also present, with protein contents around or below $100 \mathrm{~g} \mathrm{~kg}^{-1} \mathrm{DM}$ and DM contents in excess of $300 \mathrm{~g} \mathrm{~kg}^{-1}$. A broad distribution is desirable when a set of samples is selected for the development of NIR calibrations, as a way to have a better representation of the universe to be predicted subsequently in routine analysis.

\section{Spectra}

The spectra from samples scanned by reflectance (average of three readings) are presented in Figure 1. The three blocks of parallel spectra that can be seen clearly apart (Figure 1a), are explained by the adjustments on the equipment, as explained earlier. The important base line shift, impressive as it looks, does not necessarily imply that relevant spectral information cannot be extracted by suitable means. If the combined treatments of standard normal variate (SNV) and Detrend are applied, the shifts are no longer apparent (Figure 1b) and some variability appears in different bands. Information can be subsequently refined by mathematical treatments, such as derivatives and smoothing. After applying a first derivative (subtraction) of the spectral data, over a gap of five data points and a smoothing of segments of five data points (Figure 1c), lines tend to lie close together, except in bands where differences are more apparent. This seems to be the case for the segment of 2050 to $2060 \mathrm{~nm}$ (Figure 1c, insert), where curves in the lower position (samples 89, 91, 102) had the lowest CP $(83.9,81.2$ and $119.0 \mathrm{~g}$

Table 1. Composition of samples obtained by laboratory reference methods.

\begin{tabular}{lrrr}
\hline Fraction & \multicolumn{1}{c}{ Range } & Average & Standard deviation \\
\hline Dry matter, g kg-1 & $92.10-359.80$ & 182.20 & 53.60 \\
Crude protein, g kg-1 DM & $81.20-373.20$ & 205.50 & 65.80 \\
Metabolizable energy, Mj kg-1 DM & $8.82-12.47$ & 11.00 & 0.79 \\
Neutral detergent fiber, g kg-1 DM & $224.30-656.60$ & 449.80 & 77.10 \\
Acid detergent fiber, g kg-1 DM & $162.70-375.80$ & 263.00 & 45.90 \\
Soluble protein, g kg-1 DM & $20.90-209.80$ & 91.80 & 40.00 \\
Neutral detergent insoluble nitrogen, g kg-1 DM & $2.10-20.60$ & 7.50 & 3.50 \\
\hline
\end{tabular}

DM: dry matter. 
$\mathrm{kg}^{-1} \mathrm{DM}$ respectively) while those in the upper position $(17,29,33$ and 34), had the highest content (355.5, 373.2, 257.2 and $260.6 \mathrm{~g} \mathrm{~kg}^{-1} \mathrm{DM}$ respectively).

Interactance reflectance spectra also showed a base line shift as a result of fixing and regulations on the equipment (Figure 2a). This is no longer apparent after applying a scatter correction treatment (Figure 2b). Besides, changing light aperture produced differences in absorption peaks, with a weaker signal for $5 \mathrm{~mm}$ distance (Figure 3), which means that reflected light was more attenuated when it reached collecting fibers.

\section{Calibrations}

After testing several mathematical treatments, the best calibrations were selected according to their cross validation parameters. Table 2 shows the statistics of the best calibrations for the different fractions analysed and with the spectra of samples scanned by reflectance and interactance reflectance.

The selected calibrations were obtained with different math treatments. While for reflectance spectra all fractions were best predicted when calibrations were performed with a first or second order derivative, for interactance reflectance the best equations were developed with the "raw" spectra (with the exception of NDF) and a smoothing for four or five data points. In general, spectra taken by reflectance produced better results than those taken by interactance reflectance for all fractions, with the exception of NDIN, which was similar. The equations obtained in reflectance for DM, CP and ADF showed the highest statistics for certainty, with $\mathrm{R}^{2} \mathrm{CV}$ of 0.9 or higher, and a SECV lower than a third of the standard deviation (SD) of reference data. This relation between SECV and SD has been proposed as useful for evaluating an equation, which can be considered as reliable for prediction work when SD is more than three times higher than the SECV (Kennedy et al., 1996). Another criterion that can be applied is the ratio between SECV and the average of reference data for a given fraction, and in general the best equations also tended to show values below 0.1 for this relation. This was the case for DM (0.041), CP (0.082) and ADF (0.054), in the reflectance mode. For ME however, although both equations ended with a SECV of less than $5 \%$ of the reference data average, they can not be
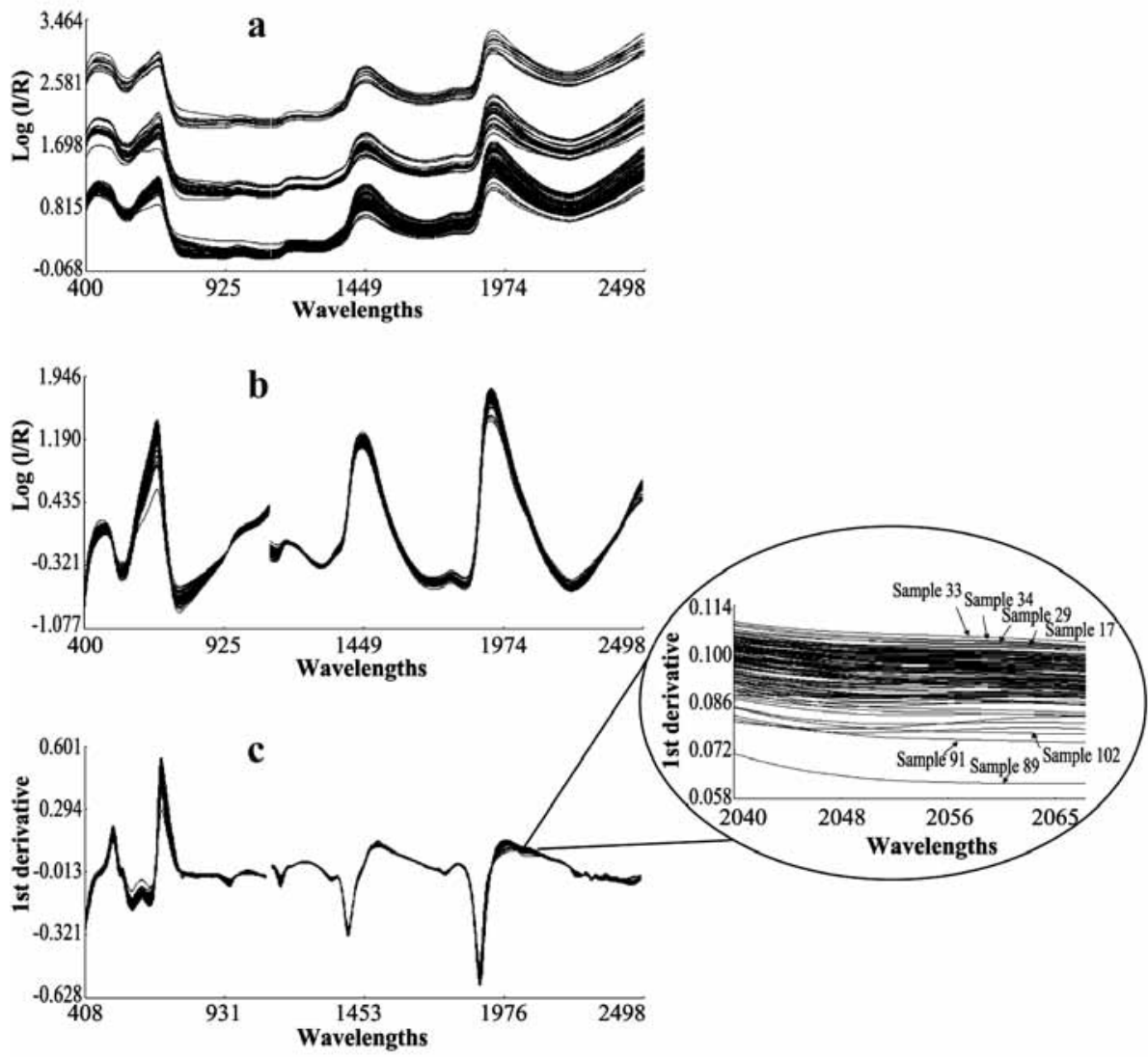

Figure 1. Reflectance spectra of fresh forage from pastures, showing original values (a) or transformed (b) by the scatter correction treatments as standard normal variance (SNV) and Detrend, or the same treatments plus a first derivative (c). Insert depicts a particular segment of the spectra where differences appear among samples of extreme protein content. 
Table 2. Statistics of best calibrations with spectra obtained by reflectance or interactance-reflectance.

\begin{tabular}{|c|c|c|c|c|c|c|}
\hline Fraction & Math treatment* & $\mathbf{R}_{\mathrm{cv}}^{2}$ & SECV & SD SECV $^{-1}$ & SECV Average & Other \\
\hline \multicolumn{7}{|c|}{ Reflectance } \\
\hline $\mathrm{DM}$ & 2,5,5,1 SNV+Detrend & 0.98 & 7.50 & 7.15 & 0.041 & \\
\hline $\mathrm{CP}$ & $1,5,5,1 \mathrm{SNV}+$ Detrend & 0.93 & 16.76 & 3.69 & 0.082 & \\
\hline ME & 2,8,8,1 SNV+Detrend & 0.80 & 0.354 & 2.23 & 0.032 & \\
\hline NDF & 2,5,5,1 SNV+Detrend & 0.80 & 33.58 & 2.22 & 0.075 & \\
\hline $\mathrm{ADF}$ & $2,10,10,1$ None & 0.90 & 13.96 & 3.20 & 0.054 & \\
\hline SP & 1,10,10,1 SNV+Detrend & 0.85 & 14.44 & 2.63 & 0.160 & \\
\hline NDIN & 2,5,5,1 None & 0.61 & 1.89 & 1.59 & 0.260 & \\
\hline \multicolumn{7}{|c|}{ Interactance reflectance (optic fiber) } \\
\hline $\mathrm{DM}$ & 0,0,3,1 None & 0.84 & 21.29 & 2.51 & 0.120 & $3 \mathrm{~mm}$ path \\
\hline $\mathrm{CP}$ & $0,0,2,1 \mathrm{SNV}+$ Detrend & 0.75 & 32.24 & 2.00 & 0.160 & $1 \mathrm{~mm}$ path \\
\hline ME & $0,0,4,1$ None & 0.63 & 0.47 & 1.65 & 0.042 & $5 \mathrm{~mm}$ path \\
\hline NDF & $1,4,4,1$ None & 0.63 & 43.87 & 1.65 & 0.097 & $3 \mathrm{~mm}$ path \\
\hline $\mathrm{ADF}$ & $0,0,5,1$ None & 0.66 & 25.53 & 1.71 & 0.096 & $3 \mathrm{~mm}$ path \\
\hline $\mathrm{SP}$ & $0,0,4,1$ None & 0.77 & 18.81 & 2.11 & 0.200 & $1 \mathrm{~mm}$ path \\
\hline NDIN & $0,0,5,1$ None & 0.66 & 1.76 & 1.71 & 0.240 & $1 \mathrm{~mm}$ path \\
\hline
\end{tabular}

DM: dry matter. CP: crude protein. ME: Metabolizable energy. NDF: neutral detergent fiber. ADF: acid detergent fiber. SP: soluble protein. NDIN: neutral detergent insoluble nitrogen. $\mathrm{R}^{2} \mathrm{cv}$ : Coefficient of determination of cross validation. SECV: standard error of cross validation. SD SECV ${ }^{-1}$ : ratio of standard deviation of reference data (calibration set) to standard error of cross validation, ratio of standard error of cross validation to average of reference data (see text for details).

* Math treatment: Derivative order (first number), subtraction gap in data points (second number), first smooth segment in data points (third number) and segment for a second smooth segment in data points (fourth number). SNV: standard normal variate (see text for details).
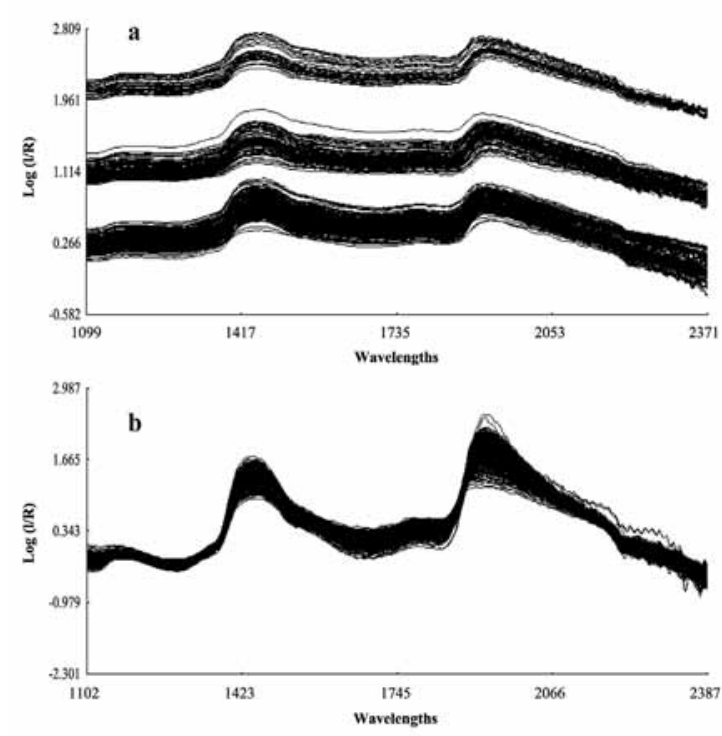

Figure 2. Interactance-reflectance (optic fiber with light path of $3 \mathrm{~mm}$ ) "raw" spectra of fresh forage from pastures, showing band shifts explained by changes in the equipment (a) and after applying a scatter correction treatment as standard normal variance (SNV), plus Detrend and a first smoothing of five data points (b).
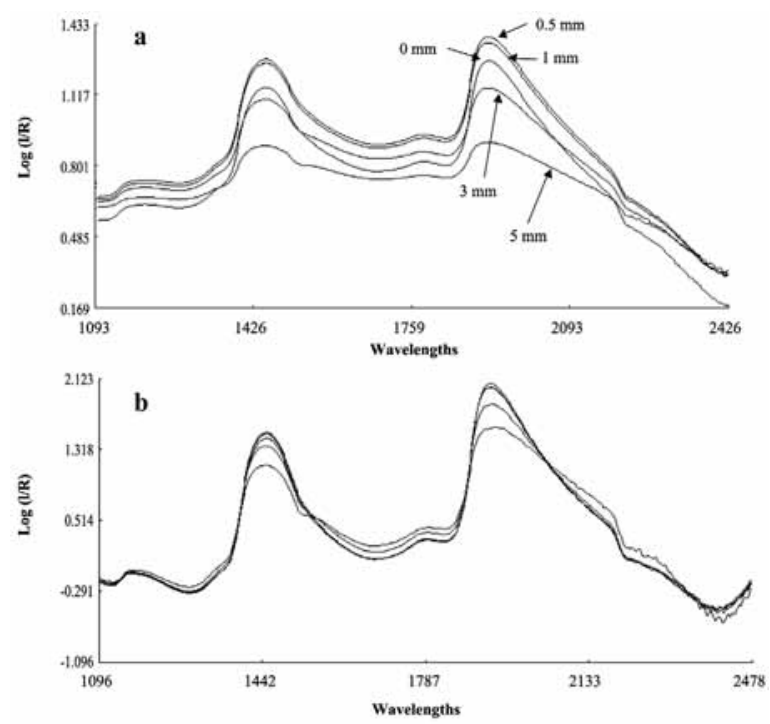

Figure 3. Mean interactance-reflectance (optic fiber) "raw" spectra of fresh forage from pastures. 3a) each curve represents mean spectra for all samples scanned with a given light aperture or pathlength from 0 to $5 \mathrm{~mm}$ (arrows); 3b) depicts the same curves, after applying scatter correction treatments as standard normal variance (SNV), and Detrend and a math treatment of smoothing segments of five data points. 

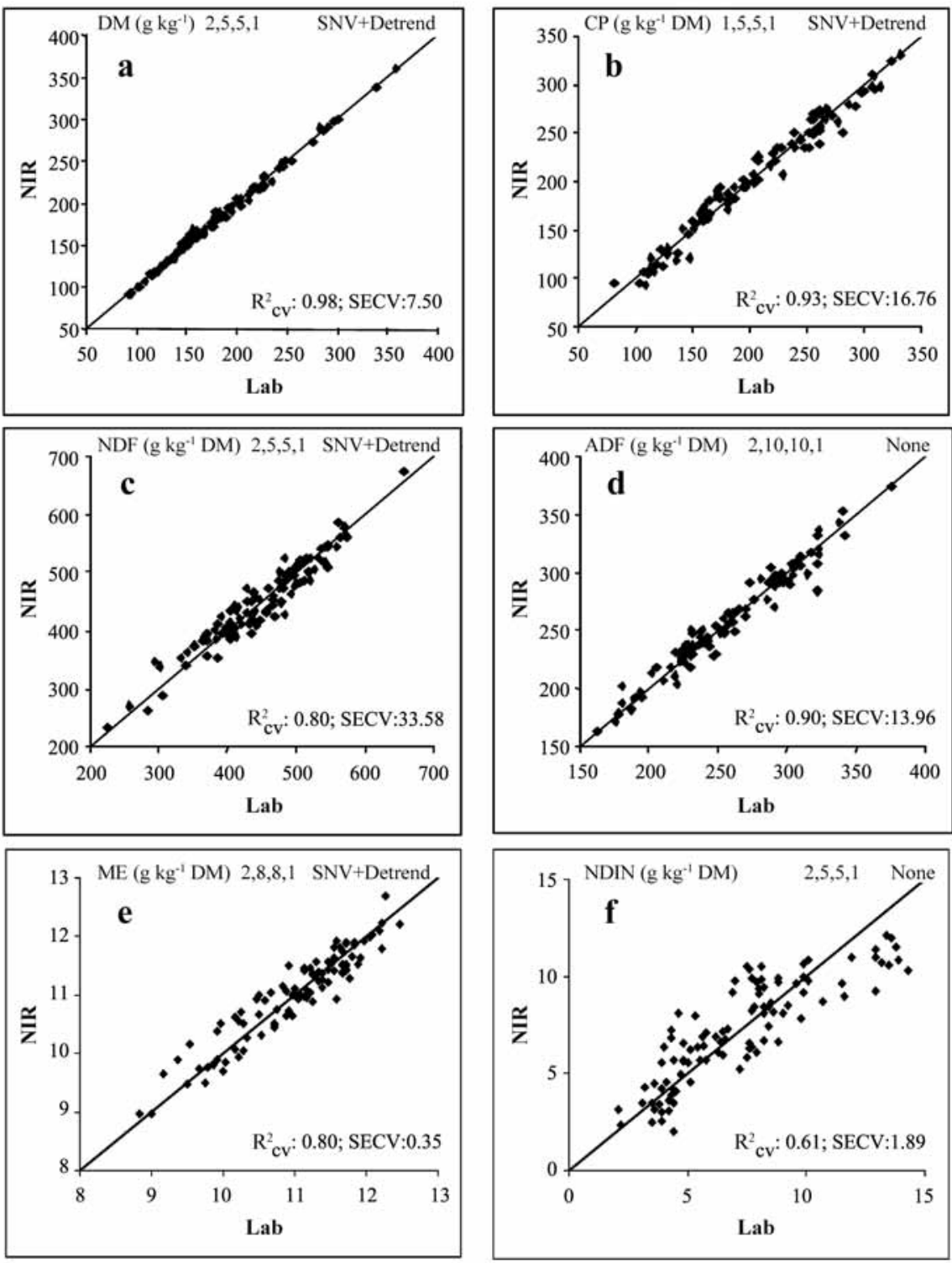

Figure 4. Near infrared reflectance (NIR) predicted versus reference (lab) data for different fractions of fresh forage from pastures. Each graph represents the best calibration obtained for DM: dry matter (a); CP: crude protein (b); NDF: neutral detergent fiber (c); ADF: acid detergent fiber (d); ME: metabolizable energy (e) and NDIN: insoluble nitrogen in neutral detergent (f).

considered as dependable because the error represented an important proportion of the variability of data. This was also the case for the equations for NDF.

The relation between NIR prediction and composition obtained by reference methods was presented for the analysed fractions (Figures 4 and 5). For each fraction, a math treatment was included. For instance, for DM (Figure 4a) a 2,5,5,1 was applied to obtain the best equation, meaning that a second derivative or subtraction over five data points, a first smoothing over a segment of five data points and a second smoothingt over one data point, plus SNV and Detrend, were employed.

It was confirmed that the best equations were those for $\mathrm{DM}, \mathrm{CP}$ and $\mathrm{ADF}$, in the reflectance mode, as their respective scatter plots depict data points closer to the diagonal equal response line. Although according to these results, NDF and the estimated ME values cannot be confidently predicted by NIRS, a strong relationship can nonetheless be seen in the configuration of the data. This reinforces the idea that spectra can recover signals from chemical bonds that in some way are related to empirical entities, such as those mentioned above. 

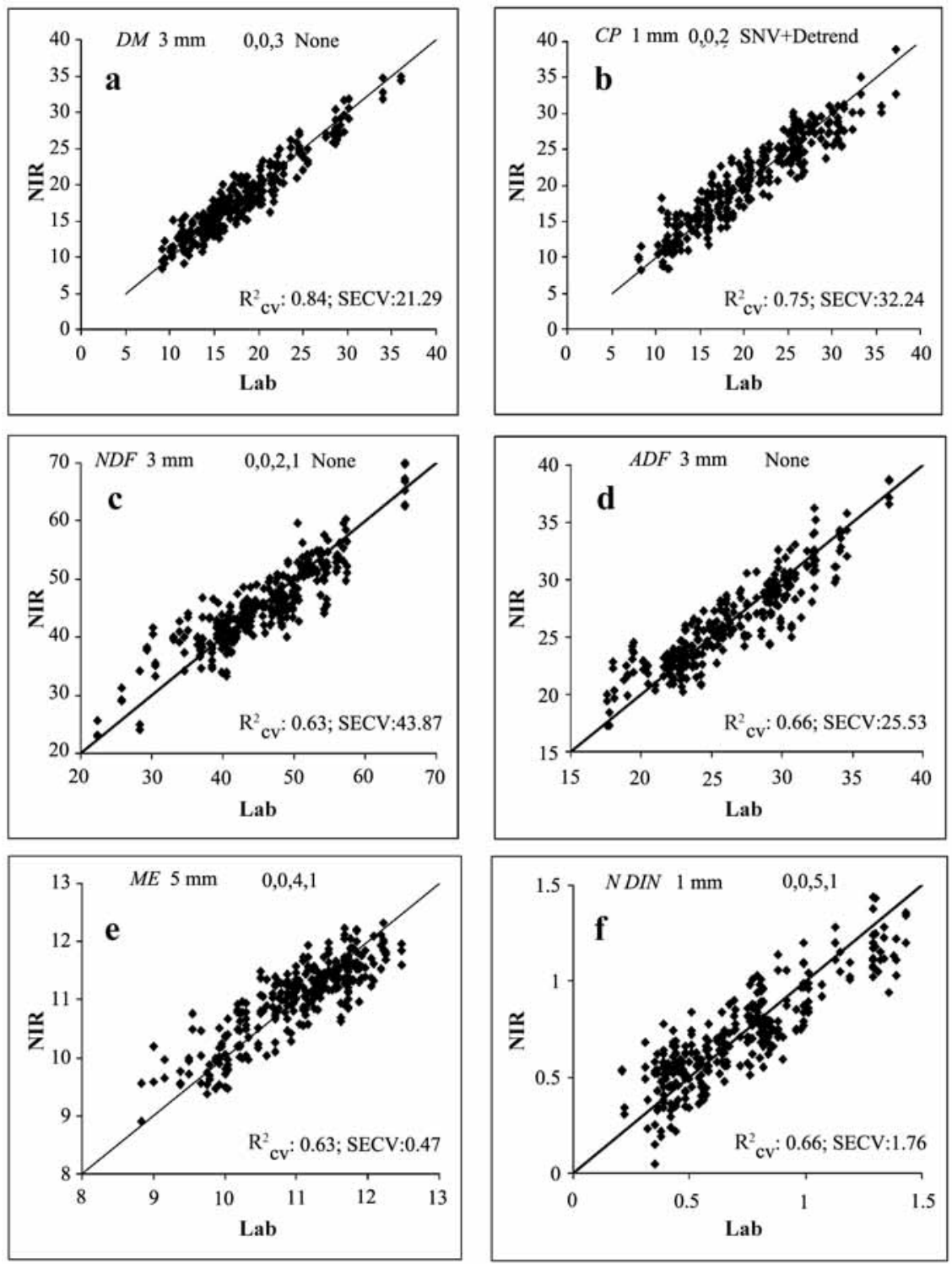

Figure 5. Near infrared reflectance (NIR) (interactance-reflectance) predicted versus reference (lab) data for different fractions of fresh forage from pastures. Each graph represents the best calibration obtained across different math treatments and light paths, for DM: dry matter (a); CP: crude protein (b); NDF: neutral detergent fiber (c); ADF: acid detergent fiber (d); ME: metabolizable energy (e) and NDIN: insoluble nitrogen in neutral detergent (f).

In line with the data presented in Table 2, which shows better results for samples scanned in reflectance, NIR predicted values (Figure 4) are closer to the equal response line (Figure 5). Although a relationship between NIR and reference data can also be distinguished using equations developed from spectra taken with fiber optics technology, the results are far from acceptable for prediction purposes. A probable explanation for these poor results could be in the surface scanned with the optic fiber probe used in this work, which is much smaller than the area covered by the forage cell employed by the transport module for the reflectance spectra. Subsequent work could be oriented to establishing if a larger number of readings per sample could improve the predictive ability of interactance reflectance technology.

The usefulness of a NIR prediction depends, on the one hand, on the accuracy of the results with respect to reference data, and on the other, on the level of error we are prepared to accept and how fast we can have the results available to make important management decisions. In the case of pasture management, the change in ME and DM content could be important features in deciding when to harvest for forage conservation, or the removal of animal stock from a given paddock. 


\section{CONCLUSION}

The results obtained in this work demonstrate that several compositional fractions of forage from different types of swards can be accurately predicted by NIRS on fresh plant material, working in reflectance with a suitable forage cell. Fiber optics technology, on the other hand, shows some potential, but results are not acceptable so far.

\section{ACKNOWLEDGEMENTS}

This work was supported by a grant from the Chilean National Fund for Science and Technology (FONDECYT), project 1000432.

\section{RESUMEN}

Predicción de la composición de pradera fresca mediante espectroscopía de reflectancia o interactanciareflectancia en el infrarrojo cercano. Disponer de técnicas bromatológicas rápidas y precisas ayudaría a optimizar decisiones en el manejo de praderas. En este trabajo se evaluó el potencial de una de tales técnicas, la espectroscopía de reflectancia en el infrarrojo cercano (NIRS) para predecir el valor nutricional de praderas al estado fresco y comparar dos formas de colectar los espectros: reflectancia e interactancia-reflectancia (fibra óptica). Se colectaron 107 muestras de praderas en las regiones templado-húmedas del sur de Chile (Los Ríos y Los Lagos). Luego de tomar sus espectros, se analizaron por métodos de referencia para materia seca(DM), proteína bruta (CP), energía metabolizable (ME), fibra detergente neutro (NDF) y ácido (ADF), carbohidratos solubles (SC), proteína bruta soluble (SCP) y $\mathrm{N}$ insoluble en detergente neutro (NDFIN). Se desarrollaron calibraciones y se eligieron como mejores ecuaciones aquellas que en una validación cruzada, mostraron un mayor coeficiente de determinación $\left(\mathrm{R}^{2} \mathrm{CV}\right)$ y un menor error estándar $\left(\mathrm{SE}_{\mathrm{CV}}\right)$. Los mejores resultados se lograron en reflectancia para DM y CP, con $\mathrm{R}^{2}{ }_{\mathrm{CV}}$ de 0,99 y 0,91, respectivamente, $\mathrm{y}$ $\mathrm{SE}_{\mathrm{CV}}$ de 6,5 y 18,4 $\mathrm{g} \mathrm{kg}^{-1}$, respectivamente. Luego se ubicaron las ecuaciones para ADF, SCP y ME, con valores $\mathrm{R}^{2}{ }_{\mathrm{CV}}$ de 0,$87 ; 0,84$ y 0,82 y $\mathrm{SE}_{\mathrm{CV}}$ de $15,88 \mathrm{~g} \mathrm{~kg}^{-1}, 15,45 \mathrm{~g}$ $\mathrm{kg}^{-1}$ y 0,34 $\mathrm{Mj} \mathrm{kg}^{-1}$, respectivamente. Las ecuaciones para NDF, SC y NDFIN, con $\mathrm{R}^{2} \mathrm{CV}$ de 0,$78 ; 0,77$ y 0,61 y $\mathrm{SE}_{\mathrm{CV}}$ de 35,$57 ; 94,54$ y $1,89 \mathrm{~g} \mathrm{~kg}^{-1}$, respectivamente; resultaron poco confiables para efectos de predicción. La técnica de interactancia-reflectancia produjo resultados inferiores para todas las fracciones.

Palabras clave: composición de praderas, predicción NIRS, espectroscopía de reflectancia en infrarrojo cercano, praderas frescas, fibra óptica.
Alomar, D., R. Fuchslocher, and M. De Pablo. 2003. Effect of preparation method on composition and NIR spectra of forage samples. Anim. Feed Sci. Technol. 107:191-200.

Alomar, D., R. Fuchslocher, and S. Stockebrand. 1999. Effects of oven- or freeze-drying on chemical composition and NIR spectra of pasture silage. Anim. Feed Sci. Technol. 80:309-319.

AOAC. 1996. Official methods of analysis of the Association of Official Analytical Chemists (AOAC). $16^{\text {th }}$ ed. AOAC International, Gaithersburg, Maryland, USA.

Deaville, E.R., and P.C. Flinn. 2000. Near-infrared (NIR) spectroscopy: an alternative approach for the estimation of forage quality and voluntary intake. p. 301-320. In Givens, D.I., E. Owen, R.F.E. Axford, and H.M Omed (eds.) Forage evaluation in ruminant nutrition. CABI Publishing, Wallingford, UK.

Deinum, B., and A. Maassen. 1994. Effects of drying temperature on chemical composition and in vitro digestibility of forages. Anim. Feed Sci. Technol. 46:75-86.

Garrido, O., and E.A. Mann. 1981. Composición química, digestibilidad y valor energético de una pradera permanente de pastoreo a través del año. 61 p. Tesis Ingeniero Agrónomo, Universidad Austral de Chile, Valdivia, Chile.

ISI. 1999. Infrasoft International, LLC (ISI) Windows Near Infrared Software, WinISI II, Version 1.02A. p. 192. Foss NIRSystems, Silver Spring, Maryland, USA.

Kennedy, C.A., J.A. Shelford, and P.C. Williams. 1996. Near infrared spectroscopic analysis of intact grass silage and fresh grass for dry matter, crude protein and acid detergent fiber. p. 524-530. In Davies, A.M.C., and P. Williams (eds.) Near infrared spectroscopy: the future waves. NIR Publications, Chichester, UK.

Licitra, G., T.M. Hernández, and P.J. Van Soest. 1996. Standardization of procedures for nitrogen fractionation of ruminant feeds. Anim. Feed Sci. Technol. 57:347-358.

Miller, C.E. 2001. Chemical principles of near infrared technology. p. 19-37. In Williams P., and K. Norris (eds.) Near-Infrared technology in the agricultural and food industries. American Association of Cereal Chemists (AACC), St. Paul, Minnesota, USA.

Osborne, B.G., T. Fearn, and P.H. Hindle. 1993. Practical NIR spectroscopy with applications in food and beverage analysis. Longman Scientific and Technical, Harlow, Essex, UK. 
Reeves, J.B. III. 2000. Use of near infrared reflectance spectroscopy. p. 185- 207. In J.P.F. D’Mello (ed.) Farm animal metabolism and nutrition. CABI Publishing, Wallingford, UK.

Tilley, J., and R. Terry. 1963. A two stage technique for the in vitro digestion of forage crops. J. Br. Grassl. Soc. 18:104-111.
Van Soest, J.P., J.B. Robertson, and B.A. Lewis. 1991. Methods for dietary fiber, neutral detergent fiber and non-starch polysaccharides in relation to animal nutrition. J. Dairy Sci. 74:3583-3597.

Williams, P.C. 2001 Implementation of near-infrared technology. p. 145-169. In Williams, P., and K. Norris (eds.) Near-Infrared technology in the agricultural and food industries. American Association of Cereal Chemists (AACC), St. Paul, Minnesota, USA. 